\title{
Mulheres desregradas: autorretratos e o corpo grotesco nos cartuns de Chiquinha
}

\author{
Maria da Conceição Pires ${ }^{1 *}$ \\ ${ }^{1}$ Universidade Federal do Estado do Rio de Janeiro, Rio de Janeiro, Brasil
}

\section{RESUMO}

A proposta deste artigo é examinar a produção quadrinística da cartunista Chiquinha, pontuando de que maneira pautas importantes dos movimentos feministas estão presentes no seu trabalho. A partir da análise dos autorretratos produzidos pela cartunista e do uso do estilo grotesco em seus desenhos, analisaremos como a cartunista produz uma crítica ao controle político sobre o corpo feminino, as formas essencializadas de compreensão dos homens e mulheres e aos padróes normativos impostos às mulheres, temas importantes para a crítica feminista. Com essa abordagem desejamos colocar em destaque o humor produzido por mulheres, para mulheres e com um direcionamento feminista, ainda carentes de um espaço significativo no campo da História Cultural do Humor.

Palavras-chave: feminismo; humor; grotesco; quadrinhos; autorretratos.

\section{Reckless women: self-portraits and the grotesque body in Chiquinha's cartoons}

\section{ABSTRACT}

This article aims to examine the production by cartoonist Chiquinha by highlighting how important guidelines of feminist movements are present in her work. By drawing attention to the analysis of the self-portraits produced by the cartoonist and the use of grotesque style in her drawings, we will analyze how the cartoonist criticizes political control over the female body, essentialized forms of understanding men and women, and the normative patterns imposed on women, which are important themes for feminist critique. Through

DOI: http://dx.doi.org/10.1590/2237-101X02004102

Artigo recebido em 26 de março de 2018 e aceito para publicação em 14 de agosto de 2018.

* Professora da Universidade Federal do Estado do Rio de Janeiro/Escola de História, Programa de Pós-graduação em História, Rio de Janeiro/RJ — Brasil. E-mail: conceicao.pires@uol.com.br. ORCID: https:// orcid.org/0000-0001-8618-4151. Este artigo é parte da pesquisa de Pós-doutoramento desenvolvida no Instituto de Estudios de América Latina y el Caribe (IEALC), Universidad de Buenos Aires (UBA). 
this approach, we want to highlight the humour produced by women, for women and with a feminist orientation, which still lacks significant space in the field of Cultural History of Humour.

Keywords: feminism; humour; grotesque; comics; self-portraits.

\section{Mujeres desordenadas: autorretratos y el cuerpo grotesco en las caricaturas de Chiquinha}

\section{RESUMEN}

La propuesta del artículo es examinar la producción de la caricaturista Chiquinha, resaltando cómo pautas importantes de los movimientos feministas están presentes en su trabajo. A partir del análisis de los autorretratos producidos por la caricaturista y del uso del estilo grotesco en sus diseños, analizaremos cómo la misma produce una crítica al control político sobre el cuerpo femenino, las formas esenciales de comprensión de los hombres y mujeres, y los patrones normativos impuestos a las mujeres, temas importantes para la crítica feminista. Con este abordaje deseamos colocar en destaque el humor producido por mujeres, para mujeres y con un sentido feminista, todavía carentes de un espacio significativo en el campo de la Historia Cultural del Humor.

Palabras clave: feminismo; humor, grotesco; historietas; autorretrato.

No artigo "Mulheres por cima", Natalie Davis explora os argumentos empregados pela medicina, o Estado e a religião para se referir ao "desregramento feminino" na Europa Moderna. Segundo a autora, para os médicos do século XVI o sexo feminino era formado por humores frios e úmidos que geravam um "temperamento instável, enganoso e falso". ${ }^{2}$ Essa perspectiva foi superada no século XVII pela ideia de que as mulheres eram possuidoras de "espíritos animais", e que isso se refletiria em suas personalidades frágeis e instáveis que as tornavam, naturalmente, inclinadas à desordem. A cura para tais desordens femininas viria do tratamento que se daria por meio da junção entre uma prática religiosa, uma educação rigorosa, o trabalho árduo e honesto e a imposição de leis e normas que estabelecessem os tipos de sujeição a que as mulheres deveriam se submeter perante seus maridos.

\footnotetext{
${ }^{1}$ DAVIS, Natalie. Mulheres por cima. In: DAVIS, Natalie. Culturas do povo. Sociedade e cultura no início da França Moderna. São Paulo: Paz e Terra, 1990. p. 107-127.

${ }^{2}$ DAVIS, Natalie. Culturas do povo. Sociedade e cultura no início da França Moderna, op. cit., p. 107.
} 
Essa imagem da mulher como naturalmente desordeira, desobediente ou caprichosa foi combatida desde o século XVI por mulheres como Christine Pisan, Aphra Benn, Mary de la Riviera Manley, entre outras, que colocaram em relevo as implicaçôes políticas e sociais do simbolismo sexual que subjaz a essa forma de abordar o que seria o "temperamento feminino". Para tais mulheres, a imagem da mulher desregrada seria a fórmula ideal para reforçar a submissão feminina, sancionando o que era tomado naquele momento como a representação da ordem social e política.

A partir desse debate, Davis se dedicou a explorar os usos da inversão sexual nas festas populares, na literatura e na vida cotidiana, colocando em relevo os significados possíveis presentes nesse processo e tentando se afastar das abordagens propostas por antropólogos e historiadores que compreendem os ritos de inversão como "fontes de ordem e instabilidade numa sociedade hierárquica". ${ }^{3}$ Conforme tais perspectivas, a inversão sexual — quando mulheres atuavam como homens ou homens se vestiam de mulheres, explorando de forma hiperbólica a imagem da mulher desregrada - teria múltiplos sentidos, tanto psicossexuais como culturais, e, no entanto, apresenta a condição inerente de ser uma válvula de escape. Ou seja, a inversão sexual poderia atuar como forma de tornar evidente as estruturas, na medida em que as invertem, e, ao mesmo tempo, expressar e aliviar os conflitos próprios do sistema sem, contudo, exercer uma mudança significativa em seu interior.

Considerando tais premissas, aqui expostas de maneira sucinta, Davis propôs explorar um outro aspecto da utilizaçáo da imagem da mulher desregrada no âmbito das artes, da literatura e das festas populares. Seu argumento é que essa imagem:

[...] nem sempre serviu para manter as mulheres em seu lugar. Ao contrário, ela era uma imagem polivalente, que poderia operar, primeiro, ampliando as opçóes de comportamento para as mulheres dentro, e mesmo fora, do casamento e, segundo, sancionando a desordem e a desobediência política, tanto para homens quanto para mulheres, numa sociedade que oferecia poucos meios formais de protesto às camadas baixas. Pôr em cena a mulher desordeira é, em parte, uma oportunidade de liberação temporária da hierarquia tradicional e estável, mas é, também, parte do conflito sobre os esforços para mudar a distribuição básica de poder na sociedade. ${ }^{4}$

Davis compartilha das ideias aventadas por Bakhtin, ${ }^{5}$ para quem a imagem do corpo grotesco - expelindo secreção, proeminente, assimétrico, distendido — presente nas festas populares da Idade Média e do Renascimento é próprio da cultura popular não oficial e se associa à ideia de transformação social. Entretanto, ao contrário de Bakhtin, Davis se dedi-

\footnotetext{
${ }^{3}$ Ibidem, p. 112.

${ }^{4}$ Ibidem. p. 112-113

${ }^{5}$ BAKHTIN, Mikhail. A cultura popular na Idade Média e no Renascimento. O contexto de François Rabelais. São Paulo: Hucitec, 1993.
} 
cou a realizar sua própria inversão ao dirigir a reflexão para os usos da imagem da mulher desregrada nas festas populares, nas artes e na literatura, ampliando com sua análise o potencial político dessa imagem.

Minha proposta é incorporar essa linha de reflexão desenvolvida por Davis na abordagem que farei da produção quadrinística da cartunista Fabiane Bento Alves Langona, que assina seus desenhos com o codinome Chiquinha. ${ }^{6}$ Os estudos sobre humor gráfico já não se situam numa condição marginal no campo das ciências humanas, em especial no âmbito da História Cultural. Entretanto, as reflexóes sobre o humor produzido por mulheres, para mulheres e com um direcionamento feminista ainda carecem de um espaço mais significativo nesse campo de estudos.

Não pretendo refletir sobre as representações das mulheres no humor, ou ainda discutir a produção de um "humor feminino" - algo de que procuro me distanciar por acreditar que incorre no risco de cairmos numa perspectiva essencialista. De uma maneira mais ampla, interessa-me analisar como pautas importantes dos movimentos feministas são incorporadas no humor produzido por mulheres cartunistas, os recursos gráficos e/ou discursivos acionados para realizar tais abordagens, e como esse tipo de humor atua como um forma de intervenção política.

Para realizar tal objetivo, examinarei pontualmente o trabalho desenvolvido por Chiquinha, que, embora refute a associação com quaisquer movimentos políticos, pois compreende que assumir esse vínculo pode representar o estabelecimento de amarras ideológicas e intelectuais, em várias entrevistas explicitou o interesse em expor, por meio de seu trabalho, à crítica às discriminaçóes sexistas, ao controle político sobre o corpo feminino, à violência sexual, além de outros temas importantes para o feminismo. Em suas palavras: "[...] me é inadmissível a ideia de, como mulher que sou, não me identificar e me ter como parte da luta feminista, mesmo que não veja o feminismo como uma cartilha fechada que devemos seguir de olhos vendados"7.

Com o exame de seu trabalho, aspiro evidenciar o que entendo ser um humor feminista, tal qual apresentado por Cintia Crescêncio, ${ }^{8}$ isto é, um humor cujo riso produzido se

\footnotetext{
' Premiada em 2012 na categoria "Melhor Publicação de Humor" do Trofeu HQ MIX, a gaúcha Fabiane Langona foi assistente de redação e arte-finalista da revista $M A D$ no Brasil entre os anos de 2005-2008. Publicou seus trabalhos no Jornal do Brasil (2005), Jornal do Comércio (POA) (2006-2007), Diário de Pernambuco (2006-2008), Zero Hora (2006-2009), O Estado de São Paulo (2010), Folha de São Paulo (2007-2015), além de revistas nacionais e internacionais. Participou de 16 exposiçóes, sendo três individuais e as demais coletivas, e tem dois livros publicados: Uma patada com carinho. As histórias pesadas da Elefoa Cor-de-Rosa e Algumas mulheres do mundo. Desde outubro de 2017 é cartunista fixa da seçáo de quadrinhos da Folha de São Paulo.

${ }^{7}$ LANGONA, Fabiane. Uma mulher cartunista? Explique-se sobre isso. Lugar de mulher é onde ela quiser. 17 mar. 2015. São Paulo. Disponível em: http://lugardemulher.com.br/uma-mulher-cartunista-explique-se-sobre-isso/. Acesso em: 4 jan. 2018

${ }^{8}$ CRESCÊNCIO, Cíntia. Quem ri por último, ri melhor: humor gráfico feminista (Cone Sul, 1975-1988). Tese (Doutorado em História) — Programa de Pós-graduação em História, Universidade Federal de Santa Catarina, Florianópolis, Brasil, 2016.
} 
diferencia por não se fundar na produção de estereótipos ou na zombaria, ${ }^{9}$ mas no "ataque aos privilégios e à liberdade monopolizada pelos homens". ${ }^{10}$ Não se trata, portanto, de um humor derrisório, tal qual abordado por Quentin Skinner, ${ }^{11}$ em que se identifica a ausência de uma reflexividade crítica e o emprego de jogos de linguagens para dar vazão a uma racionalidade cínica, produzindo, assim, um riso que legitima práticas de opressão — de classe, gênero ou raça - ao se afirmar pelo desprezo por tudo aquilo ou aqueles que se tornam alvos desse humor.

Para este artigo, me dedicarei a duas questóes: em primeiro lugar, ao exame dos autorretratos, muito frequentes nos cartuns de Chiquinha, que serão abordados com base nas discussões existentes sobre a escrita autobiográfica e da noção de autoficção. A segunda questáo que movimenta meus interesses é o emprego do estilo grotesco em seus desenhos. Para desenvolver essa análise, me debruçarei sobre a série "segredinhos revelados", que circulou nos dias 23/06, 30/06, 07/07 e 14/07/2014 na seção de quadrinhos da Folha de São Paulo, ${ }^{12}$ assinalando como a cartunista incorpora elementos próprios do estilo grotesco - em que predominam o exagero, o hiperbolismo, a profusão e o excesso ${ }^{13}$ — para falar de si e produzir um contradiscurso crítico dos dispositivos de controle social, das formas essencializadas de compreensão de homens e mulheres e dos padrôes normativos impostos às mulheres.

Antecipadamente, assinalo que minha opção analítica é pontuar os usos do grotesco na série, de uma maneira ampla, sem que isso implique uma análise minuciosa das imagens. Entendo que tal opção analítica não compromete o propósito maior deste artigo, que é dar visibilidade ao humor gráfico produzido por mulheres que abordam temáticas importantes para o pensamento feminista e que, assim, produzem uma crítica feminista.

A meu ver, enquanto o humor gráfico conquistou um espaço significativo como objeto de estudo no âmbito da História Cultural do Humor, a produção feita por mulheres permanece em condição de quase invisibilidade. É esse o espaço que intento ocupar, sem incorrer no perigo de defender a existência de uma escrita estritamente "feminina", mas ressaltando o seu caráter transgressor e político.

\footnotetext{
9 SOIHET, Rachel. Preconceitos nas charges de O Pasquim: mulheres e a luta pelo controle do corpo. Artcultura, Uberlândia, v. 9, n. 14, p. 39-53, jan./jun. 2007.

${ }^{10}$ CRESCÊNCIO, C. Quem ri por último, ri melhor: humor gráfico feminista (Cone Sul, 1975-1988), op. cit., p. 25-26.

${ }^{11}$ SKINNER, Quentin. Hobbes e a teoria clássica do riso. São Leopoldo: Editora da Unisinos, 2002.

${ }^{12}$ Por respeito aos direitos autorais, as imagens citadas não acompanharão o texto. Entretanto, disponibilizarei, no corpo do artigo, os links do acervo da Folha de São Paulo para consulta e exame por parte dos leitores e das leitoras.

${ }^{13}$ BAKHTIN, Mikhail. A cultura popular na Idade Média e no Renascimento. O contexto de François Rabelais, op. cit., p. 265.
} 


\section{Autorretratos, autoficção: estratégias para falar de si e das outras}

Alguns elementos específicos chamam minha atenção no trabalho de Chiquinha, e será sobre esses aspectos que me debruçarei a seguir. O primeiro ponto que destaco é o emprego prioritário de personagens femininas. Conforme afirmou em entrevista ao site Lugar de Mulher, colocar personagens femininas como objeto e sujeitos foi a forma encontrada para:

[...] trespassar a clássica e vilipendiosa representaçáo humorística que fizeram de nós desde os primórdios - fortemente baseada em loiras e/ou donas de casas traídas e revoltadas e/ou motoristas ruins — pra focar em questôes reais. Reais na minha experiência de mulher comum. ${ }^{14}$

O seu primeiro livro, Uma patada com carinho. As histórias da Elefoa Cor-de-Rosa, ${ }^{15}$ reúne especificamente as histórias da Elefoa Cor-de-rosa, uma personagem animal, que, junto com suas amigas Gisbelle e Janete - uma girafa e uma ursa, respectivamente - coloca em pauta temas como os padróes de beleza imputados às mulheres, relacionamentos afetivos, amorosos e profissionais, entre outras questóes, sempre a partir de uma perspectiva comportamental. Segundo a própria autora, em entrevista concedida ao Programa do Jô ${ }^{16}{ }^{\text {sua }}$ intenção quando criou a personagem era responder aos frequentes questionamentos sobre seu trabalho em uma área cuja presença masculina é maioritária.

Desse modo, a Elefoa tornou-se o ponto de partida para a cartunista discutir, por meio do humor e em quadrinhos, a legitimidade dos papéis e padróes sociais preestabelecidos, propondo rupturas e transformaçôes. Gradativamente a Elefoa foi sendo substituída por personagens humanas, todas femininas, que se alternam entre tipos variados e a própria autora, e esse é o segundo ponto que me chama a atenção: o uso constante de autorretratos e a condição de autora-personagem.

Nos cartuns em que ela figura como personagem são abordadas questôes pessoais, extraídas de suas vivências cotidianas, bem como são representados temas que figuram nos noticiários nacionais e internacionais ou que são debatidos nas redes sociais. Contudo, nem sempre as experiências narradas em primeira pessoa foram necessariamente vividas por ela. Ainda assim, esse dado não as torna inverossímeis, pois são abordados ficcionalmente episódios reais, que poderiam ser experienciados por quaisquer de suas leitoras em seu cotidiano. Ou seja, o fato de interpretar coisas reais não implica que o desfecho corresponda ao ocorrido na realidade, podendo vir a ocorrer finais inusitados que funcionam como respostas possíveis às questôes propostas.

\footnotetext{
${ }^{14}$ LANGONA, Fabiane B. A. Uma mulher cartunista? Explique-se sobre isso, op. cit.

${ }^{15}$ CHIQUINHA. Uma patada com carinho. As histórias pesadas da Elefoa Cor-de-Rosa. São Paulo: Leya, 2011.

${ }^{16}$ Fabiane Bento Alves Langona é o nome da cartunista Chiquinha. Programa do Jô. Globoplay. 30 ago., 2012. São Paulo. Disponível em: https://globoplay.globo.com/v/2116011/. Acesso em: 4 jan. 2018
} 
A categoria autoficção é oportuna para pensar o que Chiquinha faz nos seus desenhos, já que "os nomes da autora, narradora e personagem são idênticos", ela "assume esse risco". ${ }^{17}$ Segundo Figueiredo, a autoficção é "um gênero que embaralha as categorias de autobiografia e ficção de maneira paradoxal ao juntar, numa mesma palavra, duas formas de escrita, que em princípio deveriam se excluir." ${ }^{\prime 18}$

Além disso, é interessante como a autora assume a condição de estranhamento para falar de si, "olhando-se com olhos de outro", tal qual abordado por Bakhtin. ${ }^{19}$ Chiquinha também consegue empatia com suas leitoras por narrar menos os seus prazeres e mais as suas angústias, sejam estas as mais banais ou aquelas que envolvem aspectos mais complexos da sua vivência como mulher. Seria uma maneira radical de documentar as "dores, feridas e conflitos que evidenciam os seus lugares, sua diferença e, consequentemente, sua condição de gênero [...]" ${ }^{20}$

Falar de si e das outras como se fosse de si, sem que se torne um exercício de "espetacularizaçâo do eu", ${ }^{21}$ não insere seu trabalho na categoria, a meu ver, estigmatizada além de essencialista, de "quadrinhos de mulher", uma versão da chamada "literatura de mulher". Prefiro compartilhar com Dantas as hipóteses de que:

esta tendência indique a relação entre as aspiraçóes de alteridade das autoras e a cultura sexista onde inscrevem seus produtos. Outra é a de que esta escolha deflagra uma estratégia de intervençáo diante da indústria, na qual elas operam o que pode ser descrito como um falar da fronteira (Bhabha, 1998), onde os seus lugares e identidades tornam-se perpassados por trocas e deslocamentos de sentido. ${ }^{22}$

Em minha perspectiva, os autorretratos constituem uma política de autorrepresentação. Ou seja, funcionam como estratégias para tornar visíveis e dar representatividade a si, às suas experiências subjetivas e aos sujeitos sociais que partilham experiências e vivências que náo encontram visibilidade nos espaços públicos e políticos tradicionais. ${ }^{23}$ Assim, "os marcos pessoais se tornam experiências coletivas", ${ }^{24}$ bem como servem para demarcar dissidências e as singularidades que envolvem os grupos aos quais as histórias se remetem.

\footnotetext{
${ }^{17}$ VILAN, apud FIGUEIREDO, E. Autoficção feminina: a mulher nua diante do espelho. Revista Criação \& Critica, n. 4, p. 92, abr. 2010.

${ }^{18}$ FIGUEIREDO, Euridice. Autoficção feminina: a mulher nua diante do espelho, op. cit., p. 91.

${ }^{19}$ BAKHTIN, Mikhail. Estética da criação verbal. São Paulo: Martins Fontes, 2003, p. 13.

${ }^{20}$ DANTAS, Daiany F. Autobiografia de mulheres cartunistas: a aventura íntima da alteridade reinventada. Labrys, Etudes Féministes/Estudos Feministas, jan/juin 2011-jan/jun 2011, [n/p].

${ }^{21}$ SIBILIA, Paula. O show do eu: a intimidade como espetáculo. Rio de Janeiro: Nova Fronteira, 2008.

${ }^{22}$ DANTAS, Daiany F. Autobiografia de mulheres cartunistas: a aventura íntima da alteridade reinventada, op. cit.

${ }^{23}$ ACEVEDO, Mariela. Clítoris. Historietas y Exploraciones Varias. Feminismos y Textualidades. Tebeosfera, Sevilha, n. 13, dez 31, 2014. Disponível em: https://www.tebeosfera.com/documentos/revista_clitoris._historietas_y_exploraciones_varias._feminismos_y_textualidades.html. Acesso em: 4 jan. 2018.

${ }^{24}$ DANTAS, Daiany F. Autobiografia de mulheres cartunistas: a aventura íntima da alteridade reinventada, op. cit
} 
Ao utilizar os cartuns para enunciar subjetividades, Chiquinha demonstra estar ciente do espaço ocupado na mídia e da potência transformadora desse lugar, ainda que náo nos seja possível afirmar o mesmo sobre os usos dos conteúdos de suas histórias por parte do público de leitoras. Nesse caso, ainda carecemos de estudos que reflitam sobre as questôes sobre usos e apropriaçóes dos produtos da cultura de massa por parte do público, mas nos é possível aventar sobre os enfrentamentos colocados por essa forma narrativa.

Nos autorretratos encontra-se o terceiro ponto que me interessa explorar: o recurso ao grotesco para compor a autorrepresentação. Como personagem, a autora explora uma autoimagem caótica e grotesca para relatar a experiência de ser dona do próprio corpo e de suas condutas, opondo-se aos padrôes comportamentais binários de gênero, ao mesmo tempo em que ressalta sua caducidade.

Com esse tipo de abordagem, defendo a premissa de que o humor produzido por Chiquinha se distancia do humor derrisório, que busca se estabilizar às custas do reforço a estereótipos, desprezando a alteridade. Seria, portanto, um tipo de humor mais próximo do domestic humor, tal como definido por Crescêncio, a partir da leitura de Walker, e que se constitui em um humor cujas:

[...] situaçóes representadas são familiares à maioria das leitoras mulheres, a leitora primeiro reconhece sua própria experiência no relato da escritora, embora exagerada, senão distorcida pelos propósitos do humor... Depois, o humor solicita simpatia; a habilidade da escritora de fazer graça da situaçáo garante o respeito e a participaçáo da leitora; o humor torna-se uma estratégia para lidar com a frustraçáo, e a leitora sente uma ligaçáo com a escritora que consegue, simultaneamente, delinear e avançar sobre uma situação familiar e desconfortável. Finalmente, e mais importante, a leitora é sutilmente convidada a concordar com a escritora sobre a fonte do desconforto - a concordar com a premissa de que alguém ou algo está em falta em uma cultura que isola e banaliza a experiência das mulheres. ${ }^{25}$

Desse modo, Chiquinha produz um humor feminista que intenta gerar um riso subversivo, na medida em que se funda na desconstrução de discursos historicamente construídos sobre as mulheres e suas condutas. Para arrematar minha análise, convido os leitores e as leitoras a desfrutar a série "Segredinhos Revelados", produzida por Chiquinha, examinando como a adoção do grotesco representa uma recusa radical aos padrōes normativos imputados às mulheres, fazendo eco à crítica feminista que tem se empenhado em reintroduzir a questấo do "corpo e de categorias do corpo [...] na esfera do que se chama político". ${ }^{26}$

\footnotetext{
${ }^{25}$ WALKER, apud CRESCÊNCIO, Cíntia. Quem ripor último, ri melhor: humor gráfico feminista (Cone Sul, 19751988), op. cit., p. 76.

${ }^{26}$ RUSSO, Mary. O grotesco feminino. Risco, excesso e modernidade. Rio de Janeiro: Rocco, 2000, p. 70.
} 


\section{O estranho e grotesco corpo feminino}

Para abordar as imagens grotescas criadas por Chiquinha, utilizarei a categoria "grotesco" tal qual apresentada por Bakhtin, ${ }^{27}$ que refuta a simples associação das imagens grotescas com expressões denegridoras do social e cuja finalidade seja exclusivamente satírica. Em sua perspectiva, a principal propriedade do grotesco não é nem o exagero nem a condição denegridora de um acontecimento negativo. A sua riqueza estaria em destronar toda uma estrutura de vida, "negaçáo indissoluvelmente associada à afirmaçáo do novo nascente". ${ }^{28}$

Seguindo seu raciocínio, no primeiro momento a corporificação e o rebaixamento das coisas e/ou pessoas/instituiçôes atuam com a função de integrar à realidade imediata os objetos, fatos e autoridades abordados, preparando, assim, para o processo de renovaçáo que se dá pela transposição de limites e do apagamento das fronteiras, uma vez que confere novos sentidos ao que é considerado inverossímil, tornando-o, desse modo, possível.

O poderoso sopro material e corporal que as anima, destrona e renova todo o mundo das concepçôes e das estruturas medievais, com sua fé, seus santos, suas relíquias, seus mosteiros, sua falsa ascese, seu temor da morte, seu escatologismo e seus profetas. [...] O sopro material e corporal tem aqui um caráter positivo [..... ${ }^{29}$

$\mathrm{Na}$ análise proposta por Bakhtin, interessa-me sua interpretaçáo acerca da importância do corpo no interior do grotesco, isto é, a funçáo que cada parte do corpo em exposiçáa assume. O corpo grotesco é um corpo em movimento e, por isso, inacabado, em construçáo e onde as partes "ultrapassam as fronteiras entre dois corpos e entre o corpo e o mundo, onde se efetuam as trocas e as orientaçóes recíprocas", ${ }^{30}$ podendo levar uma vida independente.

Uma segunda abordagem do grotesco que me parece oportuna é a apresentada por Mary Russo, ${ }^{31}$ que, tomando como base as reflexôes de Bakhtin, reflete sobre o transbordamento de imagens do corpo feminino no interior da cultura de massas e a construção do que ela define como o grotesco feminino. Sob uma perspectiva teórica feminista, Russo vai pontuar a dimensão ambivalente das representaçôes do corpo feminino na cultura de massas do século XX. Um corpo ora sedutor, reiterando códigos moralistas de controle corporal consolidados no século XIX, ora transgressor, "identificado com a cultura 'inferior', não oficial, ou com o carnavalesco, e com a transformação social". ${ }^{32}$ Nessa perspectiva, a exposição de um corpo

${ }^{27}$ BAKHTIN, Mikhail. A cultura popular na Idade Média e no Renascimento. O contexto de François Rabelais, op. cit.

${ }^{28}$ Ibidem, p. 268.

${ }^{29}$ Ibidem, p. 272.

${ }^{30}$ Ibidem, p. 277.

${ }^{31}$ RUSSO, Mary. O grotesco feminino. Risco, excesso e modernidade, op. cit.

32 Ibidem, p. 21. 
feminino grotesco no mundo público proporciona a quebra de códigos e fronteiras preestabelecidos, na medida em que o que é colocado à mostra é um corpo abjeto e incongruente, que não compartilha regras normatizadas, desnaturalizando, desse modo, os modelos femininos construídos ao longo da história.

Russo destaca ainda a associação frequente entre o corpo grotesco e o corpo feminino. Como demonstra Dantas:

[...] pelo caráter ambíguo e ambivalente da incompletude corporal que eles comungam entre si. O corpo feminino é encarado como incompleto, secretante, "sem começo nem fim" (RUSSO, 2000, p. 84), devido às suas constantes mudanças (a ação dos hormônios preparando o organismo próximo à chegada da menstruação, a gravidez, a menopausa). Tal associação, feminino e grotesco, vai além da relação corporal de imperfeição e se espalha também pelos papéis sociais que desempenham — ou que são obrigados a desempenhar. O corpo da mulher costuma ser marginalizado e escondido - assim como acontece com os corpos grotescos — por razóes fundamentadas em uma lógica ultrapassada, que nega às mulheres alguns dos direitos que os homens possuem. ${ }^{33}$

É a partir desse ponto de vista que proponho analisar as autorrepresentaçôes corporais de Chiquinha. São corpos que não se apresentam indiferentes às representaçôes-padrão, pois expressam os excessos de tudo o que é negado à mulher idealizada. Minha premissa é que Chiquinha nos oferece uma versão contemporânea de mulher "desregrada", tal qual abordado por Davis. ${ }^{34}$ Uma mulher excedente em todos os sentidos: nos modos, nas açôes, nas feições, nos afetos, multifacetada e que apresenta formas ampliadas de comportamento que ratificam a indisciplina feminina. Assim, "pôr em cena a mulher desordeira é, em parte, uma oportunidade de liberação temporária da hierarquia tradicional e estável [...]." 35

Seu caráter político está na recusa da vitimização da personagem ou da provocação de um riso jocoso gerado a partir do olhar sobre tudo aquilo que as diferentes redes de poder (família, escola, Igreja, Estado) denominam como "imperfeiçôes". Ao contrário, o riso vem da desconstrução desses padrôes, assim como sua força e autonomia são frutos da dissidência. Assim, o corpo grotesco produzido por Chiquinha torna-se uma estratégia de expressão estética de gênero que visa a ocupar um espaço no campo das artes, transcendendo e despedaçando os estereótipos de feminilidade, uma vez que traz à luz o considerado banal, feio, imperfeito e inadequado às mulheres.

\footnotetext{
${ }^{33}$ DANTAS, Daiany; FRANÇA, Marilia G. N. O grotesco feminino nas tirinhas da quadrinista Chiquinha. Práticas discursivas, linguagens e ensino: anais do III Colóquio Nacional de Linguagem e Discurso. Natal: Ediçóes UERN, 2013. p. 75.

${ }^{34}$ DAVIS, Natalie. Culturas do povo. Sociedade e cultura no início da França Moderna, op. cit.

${ }^{35}$ Ibidem, p. 112-113.
} 
Esse é o mote da série "Segredinhos Revelados", selecionada para exame e que está disponível para consulta no acervo digital da Folha de São Paulo. Trata-se de uma série muito curta - prática comum da autora - que explora exatamente o que há de mais ignóbil e, ao mesmo tempo, prosaico das práticas cotidianas, mas que quando sáo publicizadas adquirem uma dimensão não só pessoal, mas também política.

Em todos os cartuns da série os arquétipos femininos são colocados à prova, ainda que a personagem em questão represente uma mulher branca, heterossexual, com hábitos de classe média e que se dirige a uma leitora culta. Porém, o centro da questáo é como a sua conduta corrobora para a desconstrução de uma visão essencialista do feminino, tanto estética como comportamental, largamente propalada pela mídia de massa.

Uma vez que os canais de comunicação de massa têm atuado no sentido de cristalizar padrôes comportamentais, ou, ainda, reduzir relaçôes sociais complexas a estruturas basicamente simplistas, esse tipo de quadrinho atua como uma quebra importante ao se colocar, de uma forma aparentemente despretensiosa, em dimensão radicalmente oposta.

$\mathrm{Na}$ série, além do uso frequente da escatologia — os odores emitidos pelo corpo da personagem estão sempre destacados —, suas feições são hiperbólicas — orelhas, olhos, boca, dentes, nariz e queixo desproporcionais ao tamanho da cabeça -, e o corpo apresenta características regularmente negadas nas personagens míticas femininas — seios demasiadamente grandes, em geral saindo pelos cantos das roupas, protuberâncias, pelos corporais crescendo (em oposiçấo aos corpos lisos). É um corpo que provoca o estranhamento e o desconforto àquele que o observa. ${ }^{36}$

A meu ver, é interessante que a quebra de padróes ocorra sem nenhum constrangimento por parte da personagem, a julgar pelas suas feiçôes, que expressam ora prazer, ora desinibição, ora naturalidade diante de suas ações. ${ }^{37}$ Esse aspecto é importante porque afasta a personagem e suas açôes de noçôes como culpa ou erro, uma vez que parece não corroborar com as definiçóes dos papéis sexuais. Ao contrário, há uma apropriação das práticas consideradas anti-higiênicas ou descabidas para mulheres por serem próprias do "universo masculino".

Outro aspecto que se destaca é o ambiente onde são encenadas as condutas da personagem: no banheiro e na cama, dando a entender que o ocorrido se dá antes, durante e/ou após o ato sexual, condiçáo que quebra a aura romântica que envolveria a cena em questáo. Chiquinha nos apresenta uma mulher que lava os pés na pia do banheiro, flatulenta, entediada com a demora do parceiro durante a relação sexual e que não se apresenta de lingerie

\footnotetext{
${ }^{36} \mathrm{O}$ primeiro cartum da série está disponível em: https://acervo.folha.com.br/leitor.do?numero=19899\&key word=chiQUiNhA\&anchor=5944773\&origem=busca\&pd=b0257eef843b426b94cec590f7ad8b37.

${ }^{37}$ Ver o segundo cartum da série, disponível em:

https://acervo.folha.com.br/leitor.do?numero=19906\&keyword=chiQUiNhA\&anchor=5946798\&origem=b usca\&pd=14e7a213177e615048895031a4bc10da.
} 
sensual, ao contrário, recorre a roupas íntimas do seu parceiro exatamente por não dispor de lingeries limpas, tampouco sensuais. ${ }^{38}$

Conforme Foucault, ${ }^{39}$ a repressão sexual não é o principal ou único dispositivo de controle da sexualidade; esse papel estaria a cargo dos mecanismos que produzem a sexualidade, inventando o que seria o sexo. Seguindo essa esteira reflexiva é que Butler ${ }^{40}$ vai afirmar que sexo e gênero são categorizaçóes discursivas dos corpos, ações performativas erigidas culturalmente.

Os corpos que Chiquinha torna visíveis fogem dos modelos demarcados por uma lógica cultural de poder que se dedica a produzir, serializar e materializar corpos-consumo, ${ }^{41}$ e que promove a exclusão daqueles que não se inscrevem nas formas previstas de regulação social. Desse modo, o que é caracterizado anômalo por essa cadeia de produção adquire, nos desenhos de Chiquinha, a condição de normalidade, na medida em que subverte as práticas de produção de identidades sexuais.

No livro Tiranias da visibilidade: o visível e o invisível nas sociedades contemporâneas, ${ }^{42}$ Haubert e Haroche abordam como a relação imbricada entre tecnologia, estética e política favorece mecanismos de dominação e as implicaçóes do que elas denominam "tiranias de visibilidade" para o debate político e, especificamente, para as discussóes sobre performances de gênero, erotismo, questóes relacionadas ao desejo que fogem da normatividade heterossexual e falocêntrica. Conforme essas autoras, no período contemporâneo, ser visível tornou-se um requisito para existir socialmente. No interior dessa tirania contemporânea o indivíduo passa a ser julgado e/ou apreciado pela quantidade de imagens que ele produz e compartilha, gerando uma necessidade de evidenciá-los continuamente, como forma afirmativa de estar no mundo.

Suas consideraçóes nos auxiliam a refletir sobre dois aspectos que se inter-relacionam: como os estereótipos de gênero propagados através dos recursos visuais contemporâneos vêm sendo empregados para propagar uma normatividade higienizada, corroborando com os regimes tiranos de visibilidade e, ao mesmo tempo, reforçando a ótica do binarismo (homem mulher, homo hetero etc.). O segundo aspecto é como os espaços midiáticos atuam como importantes campos de disputa na medida em que criam representaçóes, modos de ver e de olhar, que afetam o campo da cultura e da política. Nessas lutas de representaçóes, os estereótipos são recursos amplamente empregados para tornar visível tudo aquilo que não

\footnotetext{
${ }^{38}$ Ver o terceiro e o último cartum da série, disponíveis respectivamente em: https://acervo.folha.com.br/leitor.do?numero=19913\&keyword=chiQUiNhA\&anchor=5948207\&origem=b usca\&pd=b283909417941fabb268602cb60e0f79.

https://acervo.folha.com.br/leitor.do?numero=19920\&keyword=chiQUiNhA\&anchor=5949798\&origem=b usca\&pd=6b8d909e01c867992db9b73907d30596.

${ }^{39}$ FOUCAULT, Michel. História da sexualidade I: a vontade de saber. Rio de Janeiro: Graal, 1985.

${ }^{40}$ BUTLER, Judith. Problemas de gênero: feminismo e subversão da identidade. Rio de Janeiro: Civilização Brasileira, 2017.

${ }^{41}$ DIPAOLA, Esteban M. Narrativas imaginales de los cuerpos y las sexualidades: géneros y corporalidades en el filme feos, sucios y malos. Estudos Feministas, Florianópolis, v. 25, n. 3, p. 530, set./dez. 2017.

${ }^{42}$ HAROCHE, Claudine; AUBERT, Nicole. Tiranias da visibilidade - o visível e o invisível nas sociedades contemporâneas. São Paulo: Ed. Unifesp, 2013.
} 
se enquadra nos padrôes normativos. Desse modo, compreendo que, no interior da cultura de massas, os estereótipos corroboram a ordenação e categorização de pessoas, bem como a construção de referências, valores e crenças para a sociedade na qual estão inseridos.

Com a análise que propus neste artigo, coloco em destaque uma produção humorística contemporânea que se relaciona de maneira crítica com os estereótipos, deixando à mostra como estes não só propõem uma simplificação do outro, mas evocam um certo tipo de consenso que incide no reforço de redes de poder. $\mathrm{Na}$ esteira das reflexões dos teóricos críticos da cultura de massa, interessa-me discutir a produçáo de signos e símbolos através dos aparatos visuais e o modo que estes atuam como importantes mediadores para existência de valores culturais que se reproduzem nas sociedades contemporâneas.

A filosofia crítica de Benjamin, Horkheimer e Adorno se dedicou a pensar o campo da cultura observando não só os aparatos ritualísticos de organização da vida cotidiana e da política, ou seja, a relação entre estética e política, mas sobretudo como os novos recursos tecnológicos visuais e audiovisuais interferiram na vida coletiva. Esse aporte teórico contribui para a reflexão sobre como determinados produtos culturais são empregados para tornar público um valor, um compromisso e uma posição social e política, desestruturando um modo dominante de ver o mundo que se reatualiza cada vez que é reproduzido, uma vez que o uso das imagens difunde e intensifica valores dominantes, fazendo predominar aquilo que Adorno denominou enrijecimento de valores. ${ }^{43}$

A crítica da cultura de massa que esses autores desenvolveram, apesar dos seus limites, sobretudo no que tange à perspectiva macro que adotam, é importante por ressaltar a desigualdade e a ausência de liberdade dos regimes de representaçáo e de visibilidade. Nessa perspectiva, entendo que o trabalho de Chiquinha atua em sentido contrário, na medida em que desenvolve um exercício de tornar visível o que é constantemente invisibilizado, gerando abalos importantes no campo da produçâo da cultura de massas.

Como artefato cultural, o humor gráfico produzido por Chiquinha atua como um expediente simbólico que faz ressoar uma representação subversiva das mulheres, enfrentando, de modo quase insolente, as formas consolidadas de representação existentes. É nesse sentido que venho defendendo a premissa de que o humor gráfico produzido por mulheres cartunistas, abordando temáticas caras ao movimento feminista, atua como um gesto político, uma espécie de atalho inusitado para que ideias feministas possam circular, reverberar e intervir no campo da cultura, ressignificando os papéis sociais, culturais e políticos das mulheres.

Do mesmo modo que se verifica o crescimento expressivo, sobretudo no interior da grande mídia, de um humor derrisório que optou pelo abandono da reflexividade crítica e cujo intuito central é, através dos jogos de linguagens, produzir naquele que ri o sentimento de desprezo e superioridade sobre o objeto do riso, identifica-se a permanência de um humor preocupado em intervir sobre o seu presente.

\footnotetext{
${ }^{43}$ ADORNO, Theodor; HORKHEIMER, Max. Dialética do esclarecimento. Rio de Janeiro: Jorge Zahar Editores, 1986.
} 
No período contemporâneo, o humor gráfico produzido por mulheres se encontra difundido em diferentes tipos de mídias, veículos de informação e entretenimento, sejam estes declaradamente feministas ou não. $\mathrm{O}$ aspecto que me interessa destacar é sua renovação no processo de transformaçáo pelo qual passou não só o feminismo, mas os movimentos sociais de uma maneira mais ampla no período após a ditadura militar.

Assim, proponho pensar o humor gráfico contemporâneo, como o produzido por Chiquinha, como um humor cujos artifícios gráficos, estéticos e discursivos empregados - os autorretratos e o estilo grotesco - atuam no sentido de estimular um distanciamento reflexivo, contrariando construçóes simbólicas que se encontram difusas na objetividade das estruturas sociais. Do mesmo modo, os papéis assumidos pelos personagens centrais desconstroem os sistemas de representaçôes consolidados, corroborando o reforço das proposiçōes defendidas pelos movimentos feministas.

As protagonistas das suas histórias são abordadas como representantes dos grupos que historicamente foram não só ridicularizados, mas também oprimidos pelas redes de poder. Nas suas histórias, ocorre uma apropriação dos contrários e, com significativa ironia - e, por que não dizer, petulância —, ocorre a ridicularização dos decrépitos padrôes normativos imputados às mulheres. Desse modo, colabora para propor táticas de mobilização para suas leitoras que não se orientam a partir de uma racionalidade dialética e tampouco se fundam em estratégias explícitas de confronto, tal qual propalado pelas cartunistas feministas nos anos 1970/1980. Compreendo que sua energia vem da propagação, através do humor, de contracondutas que vão incidir na corrosão e na superação dos preconceitos e das expectativas de gênero, identificados em seus desenhos como um dos principais pontos de opressão feminina, e é esse aspecto que o torna contemporaneamente subversivo.

\section{Fontes}

Langona, Fabiane A. B. Uma patada com carinho. Histórias pesadas da Elefoa Cor-de-Rosa. São Paulo: Leya, 2011.

Langona, Fabiane A. B. Algumas mulheres do mundo. Rio de Janeiro: Mórula, 2014.

Acervo digital da Folha de São Paulo. Seção de quadrinhos: 23/06, 30/06, 07/07 e 14/07/2014.

\section{Referências}

ACEVEDO, Mariela. Clítoris. Historietas y Exploraciones Varias. Feminismos y Textualidades. Tebeosfera, Sevilha, n. 13, 31-XII-2014 [s/p] Disponível em: https://www. tebeosfera.com/numeros/tebeosfera_2008_tebeosfera_-2_epoca-_13.html. Acesso em: 15 mai. 2018. 
ADORNO, Theodor; HORKHEIMER, Max. Dialética do esclarecimento. Rio de Janeiro: Jorge Zahar Editores, 1986.

BAKHTIN, Mikhail. A cultura popular na Idade Média e no Renascimento. O contexto de François Rabelais. São Paulo: Hucitec, 1996.

BAKHTIN, Mikhail. Estética da criação verbal. São Paulo: Martins Fontes, 2003.

CRESCÊNCIO, Cíntia. Quem ri por último, ri melhor: humor gráfico feminista (Cone Sul, 1975-1988). Tese (Doutorado em História) — Programa de Pós-graduação em História, Universidade Federal de Santa Catarina, Florianópolis, Brasil, 2016.

DANTAS, Daiany F. Autobiografia de mulheres cartunistas: a aventura íntima da alteridade reinventada. Labrys, études féministes/estudos feministas, n. 19, jan/juin 2011-jan/jun 2011.

DANTAS, Daiany F; FRANÇA, Marilia G. N. O grotesco feminino nas tirinhas da quadrinista Chiquinha. Práticas discursivas, linguagens e ensino: anais do III Colóquio Nacional de Linguagem e Discurso. Natal: Ediçóes UERN, 2013. p. 70-78.

DAVIS, Natalie. Culturas do povo. Sociedade e cultura no início da França Moderna. São Paulo: Paz e Terra, 1990. p. 107-127.

DIPAOLA, Esteban M. Narrativas imaginales de los cuerpos y las sexualidades: géneros y corporalidades en el filme feos, sucios y malos. Estudos Feministas, Florianópolis, v. 25, n. 3, p. 1459-1471, set./dez. 2017.

FIGUEIREDO, Euridice. Autoficção feminina: a mulher nua diante do espelho. Revista Criação \& Crítica, n. 4, p. 91-102, abr. 2010.

FOUCAULT, Michel. História da sexualidade I: a vontade de saber. Rio de Janeiro: Graal, 1985.

HAROCHE, Claudine; AUBERT, Nicole. Tiranias da visibilidade — o visível e o invisível nas sociedades contemporâneas. São Paulo: Ed. Unifesp, 2013.

LANGONA, Fabiane B. A. Uma mulher cartunista? Explique-se sobre isso. Lugar de mulher é onde ela quiser. 17 mar. 2015. São Paulo. Disponível em: http://lugardemulher.com.br/ uma-mulher-cartunista-explique-se-sobre-isso/. Acesso em: 04 jan. 2018

LANGONA, Fabiane B. A. Fabiane Bento Alves Langona é o nome da cartunista Chiquinha. Programa do Jô. Globoplay. 30 ago. 2012. São Paulo. Disponível em: https://globoplay. globo.com/v/2116011/. Acesso em: 04 jan. 2018

RUSSO, Mary. O grotesco feminino. Risco, excesso e modernidade. Rio de Janeiro: Rocco, 2000. SIBILIA, Paula. O show do eu: a intimidade como espetáculo. Rio de Janeiro: Nova Fronteira, 2008.

SKINNER, Quentin. Hobbes e a teoria clássica do riso. São Leopoldo: Editora da Unisinos, 2002. SOIHET, Rachel. Preconceitos nas charges de O Pasquim: mulheres e a luta pelo controle do corpo. Artcultura, Uberlândia, v. 9, n. 14, p. 39-53, jan./jun. 2007. 